\title{
OS CAPITÃEs-MORES DO MARANHÃO E A ADMINISTRAC̣ÃO DA CAPITANIA EM TEMPO DE GOVERNADOR AUSENTE (C.1673-1751)
}

The major captains mor of Maranhão and the administration of the captaincy in time of absent governor (c.1673-1751)

\section{RESUMO}

O artigo analisa as trajetórias de 13 capitães-mores responsáveis pela administração da capitania do Maranhão, cuja capital era a cabeça do Estado do Maranhão e Grão-Pará, durante a assistência do governador e capitão-general na cidade de Belém. Embora no decorrer do período em análise a Câmara de São Luís e sargentosmores tenham exercido, ocasionalmente, o governo da capitania, os capitães-mores foram os principais e mais frequentes agentes de uma dinâmica administrativa caracterizada pelo deslocamento dos governadores e capitãesgenerais do Estado do Maranhão de São Luís para Belém, onde permaneciam a maior parte do tempo. No entanto, os capitães-mores do Maranhão, seus perfis sociais, experiências e circulação no Império português ficaram obscurecidos na historiografia. Para dar relevo às suas trajetórias este artigo baseia-se em documentação relativa aos seus serviços, símbolos de distinção pessoal e percursos na administração colonial, bem como em parâmetros conceituais e analíticos do método biográfico.

Palavras-chave: Capitães-mores; Capitania do Maranhão; Trajetórias; Estado do Maranhão e Grão-Pará; Administração colonial
Fabiano Vilaça dos

\section{SANTOS}

(1) fabianovilaca@gmail.com

Universidade do Estado do

Rio de Janeiro

Rio de Janeiro, RJ, Brasil

\section{ABSTRACT}

The article analyzes the path of 13 captains mor responsible for the administration of the Maranhao captaincies, which was the capital and head of the Maranhao state and of GraoPara, while the assistance of the governor and captain general in the city of Belem. Even though in the period in analyses the Sao Luis city consul and some sarges mor have had, on some occasion, overseeing the government of the captaincies, the captains mor were the principal and more frequent agents of a dynamic administration characterized by the transition of governors and captains generals of the Maranhao state to Belem, where they remained most of the time. However, the captains mor of Maranhao, their social profiles, experiences and flow in the Portuguese Empire ended up forgotten in the historiography. To highlight their path this article is based on documentation of their services, which are symbol of personal distinction and premier in colonial administration, as well as conceptual and analytics parameters of the biographic method.

Keywords: Captains mor; administration of Maranhao; Path; State of Maranhao and GraoPara; Colonial administration 
$\mathbf{A}$ o fazer sua entrada solene em São Luís por volta das três horas da tarde do dia 3 de setembro de 1626, para tomar posse no cargo de governador e capitão-general do Estado do Maranhão e Grão-Pará, Francisco Coelho de Carvalho (BERREDO, 1849, I. I, p. 236) finalmente reuniu sob a sua jurisdição as capitanias do Pará, do Maranhão e do Ceará, governadas até então, e separadamente, por um capitão-mor e subordinadas ao governo geral do Estado do Brasil. Todo o processo durou cerca de cinco anos, desde a criação do Estado do Maranhão, em 1621, passando pela nomeação de Francisco Coelho de Carvalho, dois anos depois, até a sua posse (ABREU, 1976, p. 111). Independente do governo geral do Estado do Brasil e diretamente subordinado a Lisboa, o Estado do Maranhão e Grão-Pará tinha como cabeça a capitania do Maranhão e como subalternas as capitanias do Pará e do Ceará.

Essa configuração administrativa sofreu uma breve alteração entre 1652 e 1654, quando as capitanias do Maranhão e do Pará foram separadas e governadas cada uma por um capitão-mor. Reunificado em 1655 e entregue o seu governo a André Vidal de Negreiros, grosso modo o Estado do Maranhão e Grão-Pará manteve sua estrutura político-administrativa até 17511, perdendo ainda no século XVII o Ceará, que em data incerta passou à jurisdição de Pernambuco, não sem a resistência dos governantes do Estado do Maranhão a essa mudança (ROLIM, 2018, p. $16-19$ e p. 43-51).

Se o Maranhão era a cabeça do Estado e sede da autoridade do governador e capitão-general, o que explicaria o provimento de capitães-mores - "não confundir com capitão-mor de ordenanças”, advertiu Caio Prado Júnior (1976, p. 306) - no governo da capitania? No período de 1673 a 1751, além dos 13 capitães-mores, dois sargentos-mores do Estado foram encarregados da administração do Maranhão pelo governador e capitão-general Artur de Sá e Meneses, assim como a Câmara de São Luís exerceu a mesma função nos interstícios marcados pela ausência do governador e a chegada de um capitão-mor ou ainda quando este se afastava da cidade para cumprir alguma missão.

A presença de capitães-mores no governo do Maranhão, portanto, pode ser explicada pela existência de uma dinâmica administrativa, sobretudo, entre 1673 e 1751, em que os governadores e capitães-generais transferiam-se de São Luís para Belém a fim de resolver questões relativas à administração e à colonização da região, deslocando o centro de poder e a sua autoridade para a capital do Pará e deixando na cabeça da repartição um capitão-mor subordinado.

Apesar da longa duração dessa prática governativa (c.1673-1751), em comparação com a existência do Estado do Maranhão e Grão-Pará (1621-1751), os 13 capitães-mores que governaram a capitania do Maranhão na ausência dos governadores e capitãesgenerais não foram listados de modo sistemático em obras de referência sobre administração colonial. Na História Geral do Brasil, Francisco Adolfo de Varnhagen relacionou cronologicamente os governadores e capitães-generais, de 1626 a 1822, precedidos dos capitães-mores anteriores à criação do Estado do Maranhão, e os capitães-mores do Pará (VARNHAGEN, 1857, t. 2, p. 455-457), e não fez qualquer menção aos capitães-mores do Maranhão de 1673 a 1751. No longo verbete "Governo" 
do Dicionário histórico-geográfico da província do Maranhão, César Augusto Marques sintetizou a legislação sobre a administração do Estado (leis, regimentos etc.) e listou os governadores e capitães-generais, precedendo-os dos capitães-mores da conquista do Maranhão, assim como Varnhagen, fornecendo dados biográficos e um relato de suas principais realizações (MARQUES, 1870, p. 223-295). Mas não deu o mesmo espaço para os capitães-mores.

Sobre esses homens que transitavam entre o Pará e o Maranhão, a historiografia já apresentou dados referentes à posse de terras e de engenhos, à exploração da mão de obra indígena e à atuação na câmara. Alguns acompanharam os governadores e capitães-generais em suas viagens de São Luís para Belém antes de serem capitãesmores e continuaram se dedicando a negócios privados quando já estavam à testa da capitania do Maranhão. Vital Maciel Parente, da família dos donatários da capitania do Cabo do Norte, praticou o cativeiro indígena mesmo enquanto substituiu Inácio Coelho da Silva no governo do Maranhão (ROCHA, 2013, p. 118). Em mais de uma ocasião, João Duarte Franco interessou-se pela compra de índios escravizados (PELEGRINO, 2015, p. 133-135), inclusive no período à frente do governo do Maranhão, tendo procurado aliar seus negócios ao exercício da vereança em São Luís, "dando calor à aceitação do novo estanque e [direito] dos escravos que viessem do sertão". ${ }^{2}$ Mateus de Carvalho de Siqueira era vereador em Belém em agosto de 1677, quando teria se envolvido em uma conspiração para depor e prender o governador e capitão-general Pedro César de Meneses (LIMA, 2006, p. 347-348). Em 1709, um ano antes de ser provido no posto de capitão-mor, José da Cunha d’Eça, dono de um engenho de açúcar no Pará e grande proprietário de terras, foi autorizado pela Coroa portuguesa a resgatar 120 escravos índios (MELLO, 2009, p. 244).

Neste artigo pretende-se esboçar um perfil social desses agentes e os contornos de suas trajetórias na administração colonial, a começar pelo governo do Maranhão. Nessa perspectiva, o silêncio sobre eles pode ser explicado por não fazer sentido a existência de dois governantes com patentes distintas, em uma mesma capitania, principalmente porque o Maranhão era a cabeça do Estado, entregue a governadores e capitães-generais nomeados para exercerem a sua jurisdição a partir de São Luís, e não a capitães-mores. Por outro lado, a historiografia clássica não atentou para a dinâmica de deslocamento dos governadores e capitães-generais para Belém como uma característica da administração do Estado do Maranhão. Se o tivessem feito, talvez abrissem espaço para os capitães-mores, ao procurar saber quem ficava responsável pelo governo da cabeça do Estado na ausência do seu titular.

Este estudo está em sintonia com os parâmetros teórico-metodológicos da renovação da escrita biográfica. Não tem a pretensão de "esgotar o absoluto do "eu'" - como se pudesse abarcar todas as dimensões da vida e todos os feitos dos capitães-mores -, mas de evidenciar as "ligações" entre o indivíduo e a sociedade (LÉVILLAIN, 2003, p. 176). Essa tendência da historiografia reflete as mudanças na concepção do gênero biográfico ocorridas a partir dos anos 1980, quando na esteira da crise de modelos interpretativos, como o marxismo e o estruturalismo, em que as ações humanas eram observadas como resultantes "de forças econômicas, sociais 
ou culturais globais", "a noção de indivíduo" e o estudo das "trajetórias pessoais" ganharam relevo (LORIGA, 2001, p. 212-213).

O conceito de "trajetória" de Pierre Bourdieu é o que dá sustentação à construção dos percursos dos capitães-mores ou de suas "histórias de vida”, em que se parte do nome próprio - daí a importância da identificação e do ordenamento cronológico dos personagens - por meio do qual se institui "uma identidade social constante e durável do indivíduo biológico em todos os campos possíveis onde ele intervém como agente" (a família, a tropa, as expedições ao sertão, o governo), "isto é, em todas as suas histórias de vida possíveis". A análise dos processos sociais que conduzem à construção das histórias de vida e a preferência que se dá nesse processo à "sucessão longitudinal”, ou seja, não linear, cronológica, mas seletiva, "dos acontecimentos constitutivos da vida considerada como história" estão ligadas diretamente à "noção de trajetória como série de posições sucessivamente ocupadas por um mesmo agente (ou um mesmo grupo) num espaço" socialmente construído (BOURDIEU, 2006, p. 185190), como a sociedade de Antigo Regime, com seus ritos, hierarquias, mecanismos de reprodução social e de remuneração de serviços.

\section{Governadores e capitães-generais em Belém}

Em 1673, após breve estadia no ano anterior, "transferiu (...) Pedro César de Meneses a sua residência do Maranhão para a cidade de Belém, onde a continuaram os seus sucessores" (BAENA, 2004, p. 113). Tempos depois, a carta régia de $1^{\circ}$ de dezembro de 1677 determinou aos oficiais da Câmara de São Luís que tão logo Inácio Coelho da Silva (1678-1682) fosse empossado, devia se dirigir à capitania subalterna e, posteriormente, informar a Coroa "das conveniências que há de se passar o governo desse Estado ao Pará". ${ }^{3}$ Àquela altura, as principais razões para a assistência de Inácio Coelho da Silva no Pará eram a continuação das obras de fortificação iniciadas por Pedro César de Meneses, a instalação dos casais de colonos que chegavam das Ilhas de Cabo Verde e dos Açores, e os que ainda viriam povoar "aquelas terras, por serem firmes e muito dilatadas, capazes de toda a agricultura", especialmente a do cacau e da baunilha. ${ }^{4}$ No final do século XVII assistiu-se no Pará à expansão da economia das "drogas do sertão", como o cacau, gênero silvestre que começou a ser cultivado de forma mais sistemática justamente a partir da década de 1670, quando os governadores passaram a se fixar em Belém (CHAMBOULEYRON, 2006; 2010).

Para conhecer melhor a extensão de sua jurisdição e precaver-se de possíveis descontentamentos dos moradores e dos camaristas de São Luís, Inácio Coelho da Silva chegou a sugerir, em consulta ao Conselho Ultramarino, sua permanência por seis meses no Maranhão e outros seis no Pará, no primeiro ano de governo. Na mesma consulta ficou acertado que a decisão de "alterar por ora a assistência do governador do Maranhão na cidade de São Luís e passar ao Pará e fazer ali cabeça do governo" seria circunstancial e, por isso, não anularia a resolução régia de 13 de agosto de 1650, pela qual "os governadores façam sua assistência no Maranhão e não passem ao Pará". Propôs-se que Inácio Coelho da Silva se orientasse pelo capítulo 19 do Regimento dos governadores e capitães-generais, de 14 de abril de 1655, e 
partisse munido de uma carta "em que Vossa Alteza lhe ordene que vá assistir no Pará, enquanto se põem com efeito a cultura do cacau e baunilhas para que tudo se execute com bom sucesso, e acabada a forma daquela cultura, se tornará para o Maranhão". Isso era necessário, segundo o parecer de um conselheiro, porque "sem a assistência ordinária dos governadores no Maranhão se arrisca aquele Estado a uma grande ruína". 5

O capítulo 19 do Regimento de 1655 afirmava a subordinação do Pará à jurisdição do governador e capitão-general do Estado do Maranhão e expressava o que a Coroa esperava em termos do seu desenvolvimento, especialmente com a exploração do cravo, recomendando que tudo fosse averiguado por intermédio de particulares e informado a Lisboa pelo governador. ${ }^{6}$ Não há qualquer menção ao seu deslocamento para Belém, muito menos a critérios de nomeação de substitutos em São Luís. Dessa forma, ao indicar que Inácio Coelho da Silva se guiasse pelo capítulo 19 do seu Regimento, o Conselho Ultramarino apresentava-Ihe uma justificativa para ir ao Pará, reforçada por uma carta que expressava os motivos da viagem e reiterava a sua obrigação de assistir no Maranhão.

O deslocamento do governador e capitão-general da cabeça do governo para a capitania subalterna do Pará e a nomeação de alguém para substituí-lo em São Luís se aproximava de uma medida adotada por capitães donatários nas ilhas atlânticas e na América portuguesa, como em São Vicente e Itamaracá: a delegação de poderes a loco-tenentes ou capitães-mores para representá-los na sua ausência em suas respectivas jurisdições, escolhidos de início pelos próprios donatários e, a partir de meados do século XVII, submetidos os indicados à apreciação do Conselho Ultramarino, precedendo a nomeação do loco-tenente pelo rei (SALDANHA, 2001, p. 162-181). No Oriente, foi constatada uma interrelação entre "capitalidade", caracterizada pela existência de um centro de poder (Goa), e "itinerância", isto é, os deslocamentos de vice-reis e governadores-gerais para visitar cidades, fortalezas ou feitorias sob a sua jurisdição, visando reforçar nos itinerários percorridos a representação da autoridade régia de que estavam investidos (SANTOS, 1999, p. 264-268).

Em suma, a dinâmica de governo no Estado do Maranhão não estava descolada de expedientes administrativos semelhantes praticados em outros domínios portugueses. Mas é preciso esclarecer que os indivíduos que representavam os governadores ausentes da cabeça do Estado receberam a patente de capitão-mor e não de locotenente, embora em última instância exercessem a loco ou lugar-tenência. Na definição de um léxico do final do século XVIII, loco-tenente era "o que faz as vezes de outrem" (SILVA, 1789, t. 2, p. 35).

Até o início da década de 1670 não há muitos detalhes sobre a circulação dos governadores entre Belém e São Luís. Sabe-se, porém, que os deslocamentos aconteceram, como no tempo de Francisco Coelho de Carvalho, o Sardo (1646-1648), que nomeou o provedor da Fazenda Manuel Pita da Veiga capitão-mor quando se dirigiu ao Pará (BERREDO, 1849, I. II, p. 395-396). Ou quando Antônio de Albuquerque Coelho de Carvalho, o velho (1667-1671), ciente da oposição que sofria no Pará, rumou em princípios de 1671 para aquela cidade, "onde entrou de noite tão dissimulado no 
rebuço das sombras, que se não percebeu a sua chegada" (BERREDO, 1849, I. II, p. 535-536).

Pelos mais variados motivos, até 1671 os governadores e capitães-generais deixaram a cabeça do Estado e se instalaram temporariamente em Belém, na maioria dos casos sem que se saiba ao certo quem foram seus loco-tenentes no Maranhão. ${ }^{7}$ Mas, de acordo com um manuscrito, aparentemente da segunda metade do século XVIII, Pedro César de Meneses (1671-1678) “estabeleceu a sua residência na cidade do Pará, sendo o primeiro general que a fixou”, enquanto seu sucessor, Inácio Coelho da Silva (1678-1682), "veio com expressa ordem da Corte de fixar a sua residência no Pará". Daí em diante, até 1751, somando-se os períodos em que se ausentaram da cabeça do Estado, os governadores e capitães-generais permaneceram mais tempo em Belém do que em São Luís (SANTOS, 2017, p. 171), contrariando, portanto, a citada resolução de 13 de agosto de 1650, segundo a qual os governadores não deviam se ausentar do Maranhão. Pode-se concluir, ainda, que a decisão régia reforçava a nomeação e o envio de loco-tenentes ao Pará. Mas a frequência das viagens e a presença cada vez mais prolongada dos governadores na capitania subalterna, depois de 1670, tiveram como efeito direto a nomeação de capitães-mores que paulatinamente se firmaram na administração do Maranhão.

\section{Capitães-mores no Maranhão}

Nas obras de referência sobre história da administração colonial no Estado do Maranhão e Grão-Pará, não foram encontradas relações nominais completas dos capitães-mores do Maranhão. Alexandre de Moura, Francisco Caldeira de Castelo Branco e Jerônimo de Albuquerque, por exemplo, são bem conhecidos nas crônicas e na historiografia por terem participado do início da ocupação do Pará e do Maranhão nas primeiras décadas do século XVII, quando "o papel principal assumido pelo capitãomor (...) foi o de conquistador” (WEHLING, 2005, p. 59-66) do território e responsável pelo estabelecimento do governo daquelas conquistas, um processo que há alguns anos passou por criteriosa revisão historiográfica (CARDOSO, 2012, p. 55-170).

Na Biblioteca Pública de Évora, contudo, há uma lista ou “catálogo" dos capitãesmores do Maranhão, possivelmente de meados do século XVIII, com os nomes de quase todos que exerceram a função. O documento foi reproduzido (Tabela 1) respeitando-se a disposição das informações no manuscrito, sobre as quais serão feitas algumas observações necessárias acerca da falta de nomes, da presença de outros que não assumiram como capitães-mores, de um interregno sem explicação e algumas lacunas identificadas, por meio da lista, em outras fontes e na bibliografia consultada. 


\begin{tabular}{|c|c|c|}
\hline Capitão-mor & Início do Governo & Data da Posse \\
\hline Alexandre de Moura & 1615 & 3 de novembro \\
\hline Geronimo de Albuquerque & 1616 & 9 de Janeiro \\
\hline Antonio de Albuquerque & 1618 & 11 de Fevereiro \\
\hline Domingos da Costa Machado & 1618 & 3 (de) Abril \\
\hline Antonio Moniz Barreiros & 1622 & 20 de Abril \\
\hline Feliciano Coelho de Carvalho & 1627 & 15 de Abril \\
\hline Antonio Cavalcante de Albuquerque & 1636 & \\
\hline Antonio Moniz Barreiros & 1642 & 3 de Setembro \\
\hline Antonio Teixeira de Mello & 1643 & 16 de Janeiro \\
\hline Manoel Pitta da Veiga & 1647 & 1 de Agosto \\
\hline Baltazar de Souza Pereira & 1652 & 16 de Novembro \\
\hline Vital Maciel Parente & 1678 & 20 de Julho \\
\hline Baltazar Fernandes (Seteiro) & 1682 & \\
\hline Baltazar de Seixas Coutinho & 1686 & 18 de Julho \\
\hline João Duarte Franco & 1698 & \\
\hline Mateus de Carvalho de Siqueira & 1704 & \\
\hline José da Cunha de Eça & 1710 & 16 (de) Outubro \\
\hline Pedro da Costa Rayol & 1714 & 18 de Outubro \\
\hline Fulano Manuel de Nóbrega & 1718 & \\
\hline D. Francisco Ximenes & 1721 & \\
\hline Damião de Basto & 1728 & \\
\hline João Álvares de Carvalho & 1732 & \\
\hline Domingos Duarte Sardinha & 1745 & \\
\hline
\end{tabular}

Tabela 1. Capitães-mores do Maranhão (1615-1745)

Fonte: Biblioteca Pública de Évora (Reservados). CVX/2-14, n 16, fl. 205. Catálogo dos Governadores do Maranhão digo dos Capitães-Mores do Maranhão

Uma primeira observação a ser feita diz respeito a indivíduos que assumiram o governo do Estado em situações especiais e aparecem na lista como capitães-mores do Maranhão. O autor da lista considerou, por exemplo, que Feliciano Coelho de Carvalho exerceu a função em 1627, ou seja, durante a primeira viagem de seu pai, Francisco Coelho de Carvalho, ao Pará, mas como capitão-mor do Maranhão e não como depositário dos poderes do pai para governar o Estado do Maranhão na sua ausência, como de fato foi (BERREDO, 1849, I. I, p. 241-242).

Outra observação diz respeito à necessidade de esclarecer algo que a lista não mencionou: a divisão do Estado do Maranhão e Grão-Pará em duas capitanias independentes, de 1652 a 1654, e as mudanças que se seguiram. Com o fim do governo-geral, o governo de cada capitania foi entregue a um capitão-mor, com jurisdições independentes, Baltazar de Sousa Pereira no Maranhão e Inácio do Rego Barreto no Pará. Ao curto período de André Vidal de Negreiros (1655-1656) à frente 
do Estado reunificado, seguiu-se a nomeação de Agostinho Correia (1656-1658) pelo próprio Negreiros para substitui-lo quando se dirigiu a Pernambuco para assumir o governo da capitania. ${ }^{9}$

Conforme a Tabela 1, houve um interregno (1652-1678) na nomeação de capitãesmores para o Maranhão, sugerindo que não houve deslocamentos de governadores e capitães-generais para Belém. Na crônica de Berredo, há uma referência que apoia essa assertiva. Em 1660, denunciando supostos excessos da jurisdição dos jesuítas sobre os índios, os camaristas de Belém propuseram uma aliança aos de São Luís, pedindo-Ihes que representassem ao governador e capitão-general do Estado, D. Pedro de Melo (1658-1662), - "(que até aquele tempo residia só na cidade de São Luís, como cabeça dele)" - sobre suas queixas e enviando, para tal, procuradores ao Maranhão (BERREDO, 1849, I. II, p. 429-430).

A lista de Évora indica, ainda, que até 1678 não houve nenhum capitão-mor no Maranhão, o que configura mais uma lacuna do documento. O sucessor de D. Pedro de Melo, Rui Vaz de Siqueira (1662-1667), ao que parece, foi responsável por retomar a prática de se transferir temporariamente de São Luís para Belém, inaugurando, por sua vez, um ritual de entrada pública na cidade que teria sido encenado por todos os seus sucessores (BAENA, 1838, p. 109-110). No entanto, observando-se a lista, constatou-se a omissão dos nomes dos que substituíram Rui Vaz de Siqueira, Antônio de Albuquerque Coelho de Carvalho, o velho (1667-1671), e Pedro César de Meneses (1671-1678) quando se ausentaram de São Luís. Como foi dito anteriormente, sabe-se que eles estiveram em Belém, mesmo que por pouco tempo e sem fixar residência na cidade.

As observações e as pesquisas complementares à lista de Évora foram consolidadas em uma segunda relação dos governantes da capitania do Maranhão (Tabela 2), circunscrita ao recorte temporal privilegiado neste trabalho. A tabela apresenta 13 capitães-mores, incluindo Pascoal Paes Parente, que substituiu Pedro César de Meneses, retifica ou completa nomes de outros capitães-mores, traz as informações sobre o provimento dos governantes e acrescenta dois sargentos-mores responsáveis pela administração da capitania no tempo do governador e capitão-general Artur de Sá e Meneses (1687-1690). Em suma, a Tabela 2 atualiza e complementa os dados contidos no anterior.

O nome de Pascoal Paes Parente, omitido na lista de Évora, surgiu de uma querela com cidadãos do Maranhão por mandar alistar seus filhos, desrespeitando isenções e privilégios da elite local (CORRÊA, 2012, p. 44). Os capitães-mores que o sucederam até Baltazar de Seixas Coutinho, inclusive, foram todos providos no posto pelos governadores e capitães-generais do Estado do Maranhão. A formalidade da nomeação de Baltazar Fernandes pela carta patente de 21 de setembro de 1682 é a única de que se tem notícia até o momento. ${ }^{10}$

A nomeação de capitães-mores foi temporariamente interrompida após uma consulta de Artur de Sá e Meneses ao Conselho Ultramarino em que pretendia saber se o capitão-mor do Maranhão precisava ser soldado e receber soldo. Os 


\begin{tabular}{l|c|c|c}
\hline \multicolumn{1}{c|}{ Capitão-mor } & & Período & Provimento \\
\hline Pascoal Paes Parente & & $1673-1678)$ & Patente do governador \\
\hline Vital Maciel Parente & & $1678-1682$ & $\begin{array}{c}\text { Patente do governador } \\
\text { e capitão-general }\end{array}$ \\
\hline Baltazar Fernandes & & $1682-1684$ & $\begin{array}{c}\text { Patente do governador } \\
\text { e capitão-general }\end{array}$ \\
\hline Baltazar de Seixas Coutinho & & $1686-1687$ & $\begin{array}{c}\text { Patente do governador } \\
\text { e capitão-general }\end{array}$ \\
\hline & Antônio de Barros Pereira & $(1689)$ & Patente régia \\
\cline { 2 - 4 } & Gonçalo de Lemos & $1689-(1691)$ & $\begin{array}{c}\text { Patente do governador } \\
\text { e capitão-general }\end{array}$ \\
\hline João Duarte Franco & Mascarenhas & $1693-1704$ & Patente régia \\
\hline $\begin{array}{l}\text { Mateus de Carvalho } \\
\text { de Siqueira }\end{array}$ & & $1704-1710$ & Patente régia \\
\hline José da Cunha de Eça & & $1710-1714$ & Patente régia \\
\hline Pedro da Costa Raiol & & $1714-1718$ & Patente régia \\
\hline $\begin{array}{l}\text { Francisco Manuel da } \\
\text { Nóbrega e Vasconcelos }\end{array}$ & & $1718-1721$ & Patente régia \\
\hline $\begin{array}{l}\text { D. Francisco Ximenes } \\
\text { de Aragão }\end{array}$ & & $1721-1727$ & Patente régia \\
\hline Damião de Bastos & & $1728-1732$ & Patente régia \\
\hline $\begin{array}{l}\text { João Álvares de Carvalho } \\
\text { Domingos Duarte Sardinha }\end{array}$ & & Patente régia \\
\hline
\end{tabular}

Tabela 2. Governantes da capitania do Maranhão (c.1673-1751)

Fonte: BPE (Reservados). CXV/2-14, n 16, fl. 205. AHU. Cód. 18, fls. 92v-93; Cód. 19, fls. 446v-447; Cód. 20, fls. 249-252 e 428v-429; Cód. 21, fls. 188v-190v e 371-371v; Cód. 22, fls. 224v-225v; Cód. 23, fls. 25-26; Cód. 24, fls. 189-191v. AHU. Projeto Resgate. Sergipe (avulsos). Cx. 1, doc. 57. APEM. Acervo Digital. Câmara Municipal de São Luís. L. 24, fls. 2-6 e 11v-13v; L. 7, fl. 56v. ANTT. RGM. D. Pedro II. L. 4, fl. 468v. (BERREDO, 1849, I. II, p. 553, 562, 600 e 635). (MARQUES, 1870, p. 251-272).

conselheiros afirmaram: "Até agora nunca houve ali capitão-mor que fosse pago; e quando se ausentavam daquela cidade [de São Luís] para o Pará, os governadores do Estado nomeavam um paisano que ficasse em seu lugar governando, cuja jurisdição e autoridade cessavam quando se tornavam a restituir àquele lugar"11, aspecto que será tratado adiante. Sendo assim, nas ausências de Artur de Sá e Meneses ficaram encarregados da administração do Maranhão os sargentos-mores Antônio de Barros Pereira ${ }^{12}$ e Gonçalo de Lemos Mascarenhas ${ }^{13}$, evitando-se, assim, o recrutamento e a remuneração de outros militares exclusivamente para suprir a falta do governador e capitão-general.

Antônio de Barros Pereira acabou falecendo em comissão na região do Rio Itapecuru antes de render a Câmara de São Luís, que se veria mais uma vez desonerada da administração da capitania, sendo substituído por Gonçalo de Lemos Mascarenhas. ${ }^{14}$ Depois do governo dos sargentos-mores, sem o título de capitão-mor, assumiu João Duarte Franco "que na união do governo do Estado era o primeiro da capitania por patente real” (BERREDO, 1849, I. II, p. 662). ${ }^{15}$ Sendo assim, desde 1654/55, quando o Estado do Maranhão e Grão-Pará foi reunificado, até 1693, os governadores e 
capitães-generais teriam provido os capitães-mores do Maranhão, com a ressalva de que muito pouco se sabe pela historiografia ou as crônicas do período colonial - a exemplo dos Anais de Berredo - sobre traslados e substituições dos governadores, no intervalo aproximadamente de 1655 a 1673.

Enquanto esses capitães-mores não chegavam, a Câmara de São Luís assumiu os encargos da administração ou do governo político da capitania, excetuando-se as atribuições militares inerentes ao ofício de capitão-mor. Em carta a Antônio de Albuquerque Coelho de Carvalho, de 16 de setembro de 1693, os camaristas declararam acerca da preparação de um carregamento de farinhas para Belém: "Neste particular e nos mais recomendados por Vossa Senhoria em vários regimentos e ordens suas, nós não descuidamos uma mínima enquanto o capitão-mor não chega; que haja de tirar-nos de nossos fracos ombros esta carga, e a passe aos seus tão suficientes". ${ }^{16}$ Cerca de dois meses depois, em 6 de novembro de 1693, a municipalidade noticiou a Antônio de Albuquerque, então em Belém:

Chegou o capitão-mor; há tempo em que nos achávamos arriados e sem forças para aturar o peso do governo; e pelo cuidado que Vossa Senhoria aplicou com sua vinda, a solicitarmos este alívio, Ihe beijamos muitas vezes a mão. Estamos Ihe dando conta e informação de tudo que se tinha obrado, e do estado das coisas de que ele já deve dar parte a Vossa Senhoria. ${ }^{17}$

O provimento de capitães-mores pela Coroa consolidou-se, sem interrupções, do final do século XVII até meados do século XVIII, substituindo-se nas cartas patentes o caráter provisório da nomeação - enquanto durasse a ausência do governador e capitão-general - pelo período de três anos geralmente atribuído aos administradores coloniais. Um exemplo de que a presença de um capitão-mor no governo do Maranhão era uma realidade assentada no cotidiano da administração local, no início do século XVIII, foi a concessão de prerrogativas a José da Cunha d' Eça idênticas às de outros governantes de capitanias com a patente de capitão-mor, isto é, um tratamento distinto "dos mais cabos que servem na dita capitania do Maranhão que é cabeça desse Estado, e governa na ausência dos governadores", tendo o rei ordenado ao governador e capitão-general Cristóvão da Costa Freire que pusesse quatro soldados à porta do capitão-mor "e que quando passar pelos corpos da guarda, que o sentinela Ihe tome arma".18

Quanto ao soldo, um indicativo da hierarquia dos governos ultramarinos (CUNHA; MONTEIRO, 2005, p. 206-208), até as primeiras décadas do século XVIII os capitãesmores do Pará e do Maranhão recebiam os mesmos 200 mil reis anuais. A exiguidade desse valor, não acrescido de propinas ou quaisquer emolumentos, já havia sido apontada por José da Cunha d'Eça. ${ }^{19} \mathrm{O}$ quadro só se modificou quando em atenção a um requerimento de D. Francisco Ximenes de Aragão, alegando a impossibilidade de se sustentar com "luzimento" no cargo e a proibição do comércio aos governantes coloniais, em virtude da qual o rei havia "concedido aos governadores das conquistas 
e capitães-mores delas maiorias de soldos", os vencimentos dos capitães-mores do Maranhão foram elevados a 400 mil reis. ${ }^{20}$

\section{Perfil social, experiências e serviços dos capitães-mores do Maranhão (c.1673-1751)}

Um grupo de 13 indivíduos circunscritos a determinado recorte histórico não constitui uma amostragem com abrangência suficiente para a construção de um perfil que se possa estender ao conjunto dos capitães-mores que serviram no Maranhão, no Pará ou, comparativamente, a outras capitanias governadas por agentes com o mesmo título. Levando-se em conta a especificidade do Maranhão - a de não ser uma capitania subordinada para onde eram enviados capitães-mores de governo, como Ceará, Rio Grande, Sergipe - uma aproximação dos perfis e das trajetórias aqui analisados com os de outros capitães-mores será feita com cautela para evitar distorções, como se houvesse um padrão rigidamente definido. Daí não se admitir que este trabalho consiste propriamente em uma prosopografia, pois "os elementos biográficos que constam das prosopografias só são considerados historicamente reveladores quando têm alcance geral” (LEVI, 2006, p. 174).

A prosopografia também pode ser definida como "a investigação da experiência comum característica de um grupo de atores na história por meio de um estudo coletivo de suas vidas", segundo Lawrence Stone (Apud. CHARLE, 2006, p. 41), em que os resultados não precisam ser generalizados. Sendo assim, metodologicamente, é possível usar os termos do questionário prosopográfico de Stone, tais como: nascimento, família/origens sociais, educação, ocupação e experiência de ofício (STONE, 1981, p. 45) como parâmetros - adaptados a cada amostragem - para o estudo do perfil social e das trajetórias dos capitães-mores, incluindo suas experiências formativas.

Não há informação precisa sobre o local de nascimento da maior parte dos indivíduos estudados. Por isso, esse dado não foi incluído nas tabelas que ajudam a compor o perfil social dos capitães-mores. Sabe-se, por exemplo, que Pascoal Paes Parente era natural de Viana do Castelo21, no Minho, José da Cunha d' Eça ${ }^{22}$ e Francisco Manuel da Nóbrega e Vasconcelos ${ }^{23}$, de Lisboa, e Pedro da Costa Raiol ${ }^{24}$, da cidade de São Luís. Os poucos que ostentavam símbolos de distinção social deviam-nos aos serviços praticados antes do governo do Maranhão, à exceção de Francisco Manuel da Nóbrega e Vasconcelos, para quem a concessão do hábito de Cristo levou em conta aquela comissão. ${ }^{25}$ Nóbrega e Vasconcelos e José da Cunha d' Eça eram os capitães de melhor qualidade social, por serem descendentes de fidalgos da Casa Real. O avô materno do primeiro teve o foro de cavaleiro fidalgo, enquanto o bisavô pelo lado paterno, o desembargador Manuel da Nóbrega, foi chanceler da Relação do Porto e secretário de uma embaixada enviada a França por D. João IV. Seu avô paterno, Francisco da Nóbrega, foi juiz do crime da Repartição do Bairro Alto, em Lisboa, e instituiu um morgado e uma capela ${ }^{26}$, de cujos rendimentos o neto usufruiu como pôde até o fim da vida. ${ }^{27}$ Único fidalgo do grupo, José da Cunha d' Eça teve renovada em si a mercê do foro de moço fidalgo da Casa Real, verificada em seu avô e em seu pai, sendo elevado a fidalgo escudeiro. ${ }^{28}$ 
Em um estudo recente sobre as trajetórias sociais e administrativas dos capitãesmores do Rio Grande e do Ceará, de 1656 a 1755 - considerando neste recorte temporal o estatuto político das referidas capitanias quanto à subordinação, respectivamente, a Pernambuco e ao Estado do Maranhão - Leonardo Paiva de Oliveira (2018, p. 112145) constatou a existência de poucos agraciados com hábitos das ordens militares, principalmente a de Cristo, e menos ainda com foros de fidalgo. Apesar de analisar uma amostragem mais numerosa, a conclusão do autor de que a pequena quantidade de cavaleiros e de fidalgos nos governos do Rio Grande e do Ceará estava diretamente relacionada à qualidade social dos indivíduos destinados a capitanias ditas "periféricas" (OLIVEIRA, 2018, p. 106) pode ser aplicada ao Maranhão. Evidentemente, se o mesmo for encarado não como a cabeça do Estado do Maranhão e Grão-Pará, mas - numa espécie de inversão provisória de estatuto político -, como uma "capitania subalterna”, administrada por um capitão-mor como o Pará, pois ao se transferir para Belém, o governador e capitão-general levava consigo todos os seus poderes e jurisdições, passando a estar igualmente radicada no Pará a representação da sua autoridade.

A formação e as experiências dos capitães-mores eram essencialmente militares, tanto daqueles nomeados pelos governadores do Estado do Maranhão, quanto dos que submeteram ao escrutínio do Conselho Ultramarino as suas folhas de serviços, nas consultas para o preenchimento do cargo. Nesse sentido, a guerra contra índios de corso ou invasores estrangeiros no Estado do Maranhão se destaca como a principal experiência dos capitães-mores, principalmente, dos quatro primeiros, e, no século XVIII, a participação na Guerra da Sucessão Espanhola (Tabela 3).

Baltazar Fernandes, então sargento-mor, comandou a primeira tropa ao sertão no tempo de Pedro César de Meneses, percorrendo o Mearim em razão dos ataques de índios tapuias dos matos e campinas do rio, que constantemente assaltavam os engenhos, roubando e matando os escravos. Na mesma época, Vital Maciel Parente dirigiu tropa ao Rio Parauaçu para castigar os índios Tremembé que haviam assassinado alguns sobreviventes de um naufrágio ocorrido nos baixios de São Roque (BETTENDORFF, 1990, p. 298-317). Embora tenha governado no início do século XVIII, Mateus de Carvalho de Siqueira contava mais de 20 anos de serviços no Estado do Maranhão, tendo sido cabo de tropas enviadas aos sertões para resgatar índios e, em mais de uma ocasião, disponibilizar recursos para a guerra contra o gentio. ${ }^{29}$ Por outro lado, a partir da administração de Francisco Manuel da Nóbrega e Vasconcelos até quase o fim do período em análise, a atuação dos capitães-mores praticamente se restringiu à guerra europeia, somando-se algumas armadas e comboios de frotas à América portuguesa e à costa da África por Vasconcelos e D. Francisco Ximenes de Aragão. 


\begin{tabular}{|c|c|c|c|c|c|c|c|}
\hline \multirow{3}{*}{ Capitão-mor } & \multicolumn{7}{|c|}{ Experiências e Serviços } \\
\hline & \multicolumn{4}{|c|}{ Guerra } & \multicolumn{2}{|c|}{ Fortificações } & \multirow{2}{*}{$\begin{array}{l}\text { Armadas/ } \\
\text { Comboios }\end{array}$} \\
\hline & Índios & $\begin{array}{c}\text { Invasores } \\
\text { Estrang. }\end{array}$ & $\begin{array}{l}\text { Rest. } \\
\text { Port. }\end{array}$ & $\begin{array}{l}\text { Suc. } \\
\text { Esp. }\end{array}$ & $\begin{array}{c}\text { Comando/ } \\
\text { função } \\
\text { militar }\end{array}$ & Reparos & \\
\hline Pascoal Paes Parente & $x$ & $x$ & & & $x$ & & \\
\hline Vital Maciel Parente & $x$ & & & & & & \\
\hline Baltazar Fernandes & $\mathrm{X}$ & $\mathrm{X}$ & & & & & \\
\hline Baltazar de Seixas Coutinho & & $x$ & & & & & \\
\hline João Duarte Franco & & $\mathrm{X}$ & $\mathrm{X}$ & & & $\mathrm{X}$ & \\
\hline Mateus de Carvalho Siqueira & $\mathrm{X}$ & $\mathrm{X}$ & & & & $\mathrm{X}$ & \\
\hline José da Cunha d' Eça & & $\mathrm{x}$ & & & $x$ & & \\
\hline Pedro da Costa Raiol & $\mathrm{X}$ & & & & & $\mathrm{X}$ & \\
\hline Francisco Manuel da N. e Vasconcelos & & & & $x$ & & & $\mathrm{X}$ \\
\hline D. Francisco Ximenes de Aragão & & & & $\mathrm{X}$ & & & $\mathrm{X}$ \\
\hline Damião de Bastos & & & & $\mathrm{X}$ & & & \\
\hline João Álvares de Carvalho & & & & $\mathrm{X}$ & & & \\
\hline Domingos Duarte Sardinha & $x$ & & & & $x$ & & \\
\hline Total & 6 & 6 & 1 & 4 & 3 & 3 & 2 \\
\hline
\end{tabular}

Tabela 3. Experiências e serviços dos capitães-mores do Maranhão

Fonte: ANTT. Mesa da Consciência e Ordens. HOC. Letra F, maço 35, n. ${ }^{\circ}$ 77. RGM. D. Pedro II. L. 28, fls. 367-368; L. 48, fl. 13. Chanc. D. Pedro II. L. 21, fls. 282v-283v. Chanc. D. João V. L. 34, fls. 142v-143v; L. 51, fls. 5v-6v; L. 72, fls. 192-193; L. 82, fls. 9-10; L. 110, fls. 174-174v. RGM.

D. João V. L. 12, fls. 291-291v. AHU. Cód. 16, fls. 47v-48v; Cód. 17, fls. 244-246; Cód. 19, fls.

446v-447; Cód. 20, fls. 249-252 e 428v-429; Cód. 21, fls. 188v-190v e 371-371v; Cód. 22, fls. 224v-225v; Cód. 24, fls. 189-191v) AHU. Projeto Resgate. Maranhão (avulsos). Cx. 4, doc. 422; Cx. 4, doc. 458; Cx. 25, doc. 2615; Cx. 28, doc. 2893. (BETTENDORFF, 1990, p. 298 e p. 316317). (BERREDO, 1849, I. II, p. 312).

A tabela acima mostra, ainda, que seis capitães-mores, ou seja, quase metade da amostragem, ocuparam alguma função militar ou trabalharam no reparo de fortificações no Estado do Brasil e no Estado do Maranhão. João Duarte Franco, por exemplo, embarcou para o Rio de Janeiro em 1651, combateu os holandeses no Cabo de Santo Agostinho e serviu em fortalezas e em outras funções naquela cidade até 1657, quando voltou a Portugal. ${ }^{30}$ José da Cunha d'Eça foi capitão de um fortim e teve ao seu encargo a superintendência das fortificações de Belém (MARQUES, 1896, p. 48), enquanto Domingos Duarte Sardinha ocupou o posto de tenente da Fortaleza da Barra, de ajudante e de capitão superintendente das fortificações do Maranhão. ${ }^{31}$

Em suma, a formação e os feitos militares destacaram-se como os principais atributos dos capitães-mores do Maranhão, além da larga experiência adquirida, sobretudo, dos primeiros capitães-mores, nas andanças pelos sertões e no trato com os índios. Alguns podem ser enquadrados na categoria dos "soldados da fortuna", homens que viram na carreira militar uma forma de ascensão social. Como Damião de Bastos e João Álvares de Carvalho, cujos feitos de armas remontavam ao teatro da Guerra da Sucessão Espanhola, e outros casos de governantes do Atlântico português no século XVII que, segundo Ross Bardwell, participaram de armadas, das lutas contra 
os holandeses, galgaram postos na hierarquia militar e acabaram no governo de capitanias subalternas (BARDWELL, 1974, p. 72-78).

Os "soldados da fortuna" eram indivíduos de baixa extração social que se distinguiam no campo de batalha e buscavam, mais do que a nobilitação decorrente dos seus feitos militares, recompensas materiais e simbólicas (MATOS, 1939, p. 12), como um foro de fidalgo, uma tença ou um hábito de cavaleiro. Além dos conhecimentos técnicos - aplicados, nos casos aqui estudados, no reparo de fortificações -, os "soldados da fortuna" ocupavam postos como o de ajudante, de sargento-mor e eram "frequentemente capitães de infantaria, mas poucas vezes de cavalos" (MATOS, 1939, p. 11).

\begin{tabular}{|c|c|c|c|c|c|}
\hline \multirow[b]{2}{*}{ Capitão-mor } & \multicolumn{5}{|c|}{ Posto Militar } \\
\hline & $\begin{array}{l}\text { Sargento- } \\
\text { mor do } \\
\text { Estado }\end{array}$ & $\begin{array}{l}\text { Sargento- } \\
\text { mor do } \\
\text { Pará }\end{array}$ & $\begin{array}{l}\text { Ten. } \\
\text { Cav. }\end{array}$ & $\begin{array}{l}\text { Ten. } \\
\text { Inf. }\end{array}$ & $\begin{array}{l}\text { Cap. } \\
\text { Inf. }\end{array}$ \\
\hline Pascoal Paes Parente & $\mathrm{x}$ & & & & \\
\hline \multicolumn{6}{|l|}{ Vital Maciel Parente } \\
\hline Baltazar Fernandes & $\mathrm{X}$ & & & & \\
\hline Baltazar de Seixas Coutinho & & & & & $\mathrm{X}$ \\
\hline João Duarte Franco & & $\mathrm{X}$ & & & \\
\hline Mateus de Carvalho Siqueira & & $\mathrm{X}$ & & & \\
\hline José da Cunha d' Eça & & & & & $\mathrm{X}$ \\
\hline Pedro da Costa Raiol & & $\mathrm{X}$ & & & \\
\hline Francisco Manuel da N. e Vasconcelos & & $\mathrm{X}$ & & & \\
\hline D. Francisco Ximenes de Aragão & & & $\mathrm{X}$ & & \\
\hline Damião de Bastos & & & & $\mathrm{X}$ & \\
\hline João Álvares de Carvalho & & & & & $\mathrm{X}$ \\
\hline Domingos Duarte Sardinha & & & & & $\mathrm{X}$ \\
\hline Total & 2 & 4 & 1 & 1 & 4 \\
\hline
\end{tabular}

Tabela 4. Postos militares dos capitães-mores quando assumiram o governo do Maranhão Fonte: ANTT. Mesa da Consciência e Ordens. HOC. Letra F, maço 35, n. ${ }^{\circ}$ 77. Chanc. D. Afonso VI. L. 32, fls. 34-34v. AHU. Cód. 16, fls. 47v-48v; Cód. 17, fls. 244-246; Cód. 19, fls. 446v-447; Cód. 20, fls. 249-252 e 428v-429; Cód. 21, fls. 188v-190v e 371-371v; Cód. 22, fls. 224v-225v; Cód. 24, fls. 189-191v. (ROCHA, 2013, p. 25-39; 83-84; 274).

De acordo com a Tabela 4, dois sargentos-mores do Estado (nomeados para o Maranhão) e quatro do Pará, um tenente de infantaria, um tenente de cavalaria e quatro capitães de infantaria foram alçados ao posto de capitão-mor do Maranhão, corroborando a descrição de Matos. D. Francisco Ximenes de Aragão foi uma exceção não apenas por ser o único oficial de cavalaria, mas também por pertencer à ordenança - e não à tropa regular ou paga, como os demais, - sendo este elemento indicativo de qualidade social mais elevada. ${ }^{32}$ Em termos comparativos, tanto em relação à qualidade social quanto à formação e experiências, estes 13 capitães-mores podem ser equiparados aos do Pará, ao menos os que governaram esta capitania na primeira metade do século XVIII (SANTOS, 2015, p. 669-671). 


\section{A administração do Maranhão em tempo de governador ausente}

Para Francisco Adolfo de Varnhagen, os capitães-mores deviam ser considerados "como agentes subalternos do governador e como seus verdadeiros delegados militares, e até certo ponto administrativos, nas capitanias de menos conta e nas vilas" (VARNHAGEN, 1857, t. 2, p. 79). O autor da História Geral do Brasil afirmou, ainda, que no decorrer do processo de colonização da América a Coroa portuguesa nomeou para algumas capitanias "capitães-mores trienais e geralmente ficaram sujeitos aos governadores, e destes recebiam regimentos parciais, quando os não traziam do Reino" (VARNHAGEN, 1857, t. 2, p. 79).

Embora o Maranhão não fosse uma capitania subalterna na estrutura políticoadministrativa do Estado do Maranhão e Grão-Pará, sendo, ao contrário, a cabeça daquela jurisdição, adquiria uma condição especial e transitória de subordinação ao governador e capitão-general residente no Pará, como já foi dito. Mesmo assim, alguns pontos levantados por Varnhagen correspondiam a situações concretas verificadas no cotidiano da administração dos capitães-mores em São Luís: governavam por meio de regimentos ou instruções específicas e eram, de fato, delegados ou lugar-tenentes dos governadores ausentes. Os regimentos eram importantes para se observar a delegação de poderes pelos monarcas lusos aos seus oficiais, em Portugal e no ultramar, cumprindo, portanto, uma função ordenadora. Segundo Francisco Cosentino, "os regimentos constituem um instrumento que nos permite compreender não só o desencadeamento da política ultramarina portuguesa na América”, assim como possibilitam "maior conhecimento do papel, funções e poderes" (COSENTINO, 2009, p. 203-204) de oficiais régios em Portugal e de agentes da administração colonial, fossem eles governadores, ouvidores, provedores da Fazenda ou, capitães-mores. Para Marcos Fonseca "o papel dos capitães-mores na administração das capitanias, contudo, não foi analisado com muita profundidade. Parte da historiografia não deu muita atenção ou importância às atribuições dos cargos dos capitães-mores, bem como os seus papéis nos governos e nas administrações das capitanias" (FONSECA, 2018, p. 11).

Os capitães-mores do Maranhão nunca tiveram um regimento próprio, tanto que em 1751, quando teve início uma outra fase da sua história administrativa, o governador e capitão-general Francisco Xavier de Mendonça Furtado acusou a falta desse instrumento normativo, sugerindo a adoção provisória do regimento do governo de Santa Catarina ou da Colônia do Sacramento (MENDONÇA, 1963, t. 1, p. 141-142). No Pará, ao contrário, os capitães-mores contavam com o Regimento de 5 de junho de 1669, embora ele tenha perdido muito da sua efetividade devido à assistência cada vez mais prolongada dos governadores em Belém (BERREDO, 1849, I. II, p. 544), sobrepondo os seus poderes e jurisdições, consignados no Regimento de 1655, às prerrogativas dos capitães-mores do Pará.

Na documentação relativa à administração do Maranhão foram encontradas menções a instruções e diretrizes deixadas à partida pelos governadores e capitãesgenerais ou emitidas quando já se encontravam em Belém. Como em um ofício enviado por Artur de Sá e Meneses à Câmara de São Luís, em 1689, em que tratou da morte 
do sargento-mor Antônio de Barros Pereira e do envio de um substituto, Gonçalo de Lemos Mascarenhas, a quem a Câmara deveria entregar "o regimento que tinha dado ao sargento-mor [falecido], e os mais papeis que ao governo conduzem".33 Outro exemplo da condução do governo à distância aparece na carta de D. Manuel Rolim de Moura à Câmara de São Luís, de 6 de outubro de 1704, em que refirmava a promessa de conceder aos moradores mais índios para expedições aos sertões, conforme ordenara previamente ao capitão-mor do Maranhão. ${ }^{34}$

O único regimento completo que se conhece até o momento foi passado por Francisco de Sá de Meneses a Baltazar Fernandes, em 1682. Composto de 15 capítulos, trazia no título a expressão da sua duração: "Regimento que há de guardar Baltazar Fernandes sargento-mor deste Estado ao qual tenho nomeado por capitão-mor desta capitania de São Luís do Maranhão para exercitar este posto enquanto na de Belém do Grão-Pará durar a minha ausência". ${ }^{35}$ Continha instruções gerais sobre o modo correto de conduzir o governo, assistência aos missionários, aldeamento dos índios, auxílio às obras de fortificações, disciplina da tropa e precauções quanto à arribada de navios estrangeiros. Ao capitão-mor foi concedido o poder de confirmar numbramentos (nomeações) de sargentos e alferes já feitos pelo governador e capitãogeneral, mas não o de realizar promoções a estes postos ou dar baixa a soldados e oficiais, sendo-Ihe permitido, no entanto, conceder licenças. Essas atribuições se aproximavam do que previa o Regimento dos capitães-mores do Estado do Brasil, de 1663, também com a ressalva de que "os capitães não poderiam prover ofícios ou patentes por direito próprio, já que este ato não pertencia a sua jurisdição”, mas sim à do governador-geral. Nesse sentido, segundo Marcos Arthur Viana da Fonseca, "com relação ao governo militar de cada capitania em que haviam sido nomeados, a autoridade dos capitães estava reduzida em treinamento das tropas e em relatórios destacando necessidade de munição, armas e de reparos em fortalezas" (FONSECA, 2018, p. 77-78).

Como se pode perceber, as instruções dadas aos capitães-mores do Maranhão pelos seus superiores eram pontuais e seus poderes e jurisdições, por conseguinte, restritos. Em 1707, ante a demanda da Câmara de São Luís de uma tropa de guerra contra índios de corso, Mateus de Carvalho de Siqueira precisou consultar o capitão-general em Belém, pois, além de não dispor da quantidade de homens para a empreitada, "não tinha jurisdição para tão grande despesa da Real Fazenda sem ordem do governador". ${ }^{36}$ Diferentemente, aos capitães-mores do Pará - cujo Regimento era mais detalhado (29 capítulos) - era facultada, por exemplo, jurisdição para prover temporariamente (o Regimento não estipulava a duração do provimento) os postos de Guerra, Fazenda e Justiça (capítulo 5) ${ }^{37}$, ainda que, na prática, tivessem sua autoridade restringida pela presença do governador e capitão-general em Belém.

Na correspondência de Francisco de Sá de Meneses, em Belém, para Baltazar Fernandes, em São Luís, há indícios de que mesmo com um regimento provisório, o capitão-mor do Maranhão cuidava de problemas do cotidiano da administração fora do âmbito dos assuntos estritamente militares. Na carta de 26 de março de 1683, por exemplo, o governador e capitão-general mostrou saber das dificuldades 
na arrematação dos dízimos no Maranhão e deu especial atenção à questão dos aldeamentos indígenas. ${ }^{38}$

Em certas ocasiões, entretanto, os capitães-mores do Maranhão receberam poderes excepcionais para resolver problemas específicos da administração, como aqueles relatados por José da Cunha d'Eça ao rei ao agradecer sua nomeação para o governo da capitania. Por haver muitos soldados presos e demora no pronunciamento das sentenças, "por causa do[s] governadores às vezes passarem de ano que não vem a esta cidade [de São Luís]", segundo o capitão-mor, os efetivos da infantaria ficavam ainda mais reduzidos, sendo suficientes apenas para guarnecer a fortaleza da barra e alguns baluartes, em caso de uma invasão. Por isso, solicitou permissão ao rei para sentenciar os soldados com o ouvidor, como estava previsto no Regimento dos capitães-mores do Pará, tendo o ouvidor do Maranhão recebido autorização para despachar os processos dos soldados presos "com a pessoa a quem ficar encarregado o governo da praça”, quando o governador e capitão-general se afastasse dela por mais de um mês ${ }^{39}$ - o que estava fadado a acontecer, uma vez que só a viagem entre São Luís e Belém durava mais ou menos o mesmo tempo de navegação.

Esses episódios cotidianos ocasionavam choques entre capitães-mores e outros oficiais régios e agentes designados para alguma comissão, resultando em queixas e censuras por comportamentos excessivos. Nesse sentido, e sem querer culpar apenas os capitães-mores, João Álvares de Carvalho recebeu sucessivas repreensões por desrespeitar a jurisdição de oficiais da Justiça e da Fazenda. ${ }^{40}$ Ocorre que nos conflitos provocados por dúvidas sobre os limites da autoridade ou de competência dos capitães-mores, os demais agentes envolvidos (ouvidores, provedores da Fazenda etc.) costumavam defender suas prerrogativas jurisdicionais com base nos seus respectivos regimentos.

Em ofício de 15 de agosto de 1729, Matias da Costa e Sousa, provedor-mor da Fazenda do Estado do Maranhão, afirmou com base em seu regimento que podia ordenar as despesas com pólvora e munições para as escoltas e salvas de costume, por serem ordinárias, "sem ordem dos governadores e muito menos dos capitães maiores", como queria Damião de Bastos, "dizendo que na ausência do general fica ele com a mesma jurisdição". ${ }^{41}$ Cinco dias depois, o capitão-mor representou ao rei defendendo-se da acusação de exorbitar suas competências e argumentando: "no tempo que vai o general para o Pará e eu aqui fico governando é necessário haver expediente e despacho por não padecerem as partes e me parece que o fazer Vossa Majestade aqui capitão-mor e no Pará não foi senão para que na ausência do general haja que[m] Ihe defira". No entendimento de Damião de Bastos, era isso que acontecia em todas as "províncias" ultramarinas sempre que o superior se retirava, como se a sua autoridade e jurisdição fossem automaticamente transferidas para um substituto. Sendo assim, para o capitão-mor, nenhuma despesa devia ser feita sem o consentimento e a aprovação de quem estava governando, e como era quem governava na ausência do general cabia-Ihe autorizar as despesas necessárias, dentre outras razões, "porque Vossa Majestade me fez capitão-mor deste Estado que em ausência do general ninguém aqui manda mais do que eu" ${ }^{42}$ 
Nos meses seguintes a questão chegou ao conhecimento do governador e capitão-general, em Belém, o que levou Alexandre de Sousa Freire a escrever a Lisboa pedindo instruções acerca dos procedimentos que o capitão-mor deveria adotar com os oficiais da Fazenda na sua ausência, diante da falta de regimento para o governo do Maranhão. A resposta não foi nada favorável às pretensões de Damião de Bastos:

(...) o capitão-mor não tem, nem pode ter jurisdição alguma sobre o provedor-mor da Fazenda (...); e só no caso em que fique governando, poderá passar as ordens que os governadores podem passar, e isto não como capitão-mor, mas como governador - cujo cargo exercita - e sub-rogado [no sentido que a palavra tem de estar no lugar de outrem]; o que se não deve de entender a respeito dos comuns, e ordinários despachos, porque Sua Majestade encarregar especialmente algumas diligências ao governador, estas não pode mandar fazer o capitão-mor seu substituto, ou outra qualquer pessoa que o seja. ${ }^{43}$

O capitão-mor reagiu à decisão régia pedindo um regimento ou autorização para usar o regimento dos capitães-mores do Pará. O requerimento foi submetido ao parecer de João da Maia da Gama, antigo governador e capitão-general, segundo o qual os capitães-mores do Maranhão "não têm regimento, nem o tiveram porque a antiga assistência dos governadores gerais era no Maranhão com a qual ficava escusado o dito regimento por não ter [o capitão-mor] jurisdição mais do que para seguir as ordens do seu superior". O "contrário sucedia no Pará aonde não iam os generais, nem assistiam pelo que indo Marçal Nunes [da Costa], (...) pediu regimento para o seu posto de capitão-mor, e se lhe deu em mil seiscentos e sessenta e nove com ampla jurisdição". ${ }^{44}$ O parecer reafirmava como "verdadeiro regimento" dos capitães-mores do Maranhão as ordens do governador e capitão-general, tal como aquelas passadas por Francisco de Sá de Meneses a Baltazar Fernandes, em 1682, com o título de "Regimento" e a ressalva de que valeriam enquanto durasse a sua ausência. João da Maia da Gama não propôs qualquer inovação significativa na dinâmica administrativa do Estado do Maranhão, embora recomendasse que os capitães-mores em São Luís recebessem um regimento próprio "ao menos para saberem a jurisdição ordinária que devem ou podem ter na ausência dos generais" para atalhar as dúvidas e os conflitos de jurisdição e com a declaração expressa da sua sujeição ao governador e capitão-general.

\section{Depois do Maranhão}

Para a maioria dos capitães-mores estudados, a administração da capitania foi a primeira e única experiência deste tipo em carreiras orientadas, de ordinário, para a atividade militar. Como é possível observar na Tabela 5, apenas três ocuparam um segundo ou terceiro governo ultramarino. Acredita-se, a priori, que após se desincumbirem do cargo os demais se voltaram mais amiúde, pois nunca os abandonaram, para os seus negócios privados. Dentro do grupo, houve também quem fizesse escolha completamente distinta. Como José da Cunha d'Eça, que depois de 
viúvo e de ser capitão-mor, abraçou por volta de 1723 a vida clerical e, sendo homem de fortuna, construiu uma igreja na ribeira do Rio Mearim dotando-a de paramentos, escravos, terras e um curral de gado (MARQUES, 1896, p. 47-48).

Os capitães-mores cujas experiências de ofício se constituíram mais na Europa ou no mar do que em terras americanas e, em princípio, possuíam menos interesses particulares arraigados no espaço colonial, buscaram novas oportunidades na administração do Império. Dessa forma, uma análise dos circuitos governativos percorridos, dos possíveis nexos entre os diferentes postos e do que significavam em termos de promoção no Real Serviço complementa o estudo das trajetórias dos 13 capitães-mores do Maranhão.

\begin{tabular}{l|c|c|c}
\hline \multicolumn{1}{c|}{ Capitão-mor } & \multicolumn{2}{c}{ Governos } & \multicolumn{1}{c}{$\mathbf{2}^{\circ}$} \\
\cline { 2 - 4 } & Maranhão & & \\
\hline Pascoal Paes Parente & Maranhão & & \\
\hline Vital Maciel Parente & Maranhão & & \\
\hline Baltazar Fernandes & Maranhão & & \\
\hline Baltazar de Seixas Coutinho & Maranhão & & \\
\hline João Duarte Franco & Maranhão & & \\
\hline Mateus de Carvalho Siqueira & Maranhão & & \\
\hline José da Cunha d' Eça & Maranhão & & \\
\hline Pedro da Costa Raiol & Maranhão & Cabo Verde & \\
\hline Francisco Manuel da Nóbrega e Vasconcelos & Maranhão & Ceará & \\
\hline D. Francisco Ximenes de Aragão & Maranhão & Cacheu & Benguela \\
\hline Damião de Bastos & Maranhão & & \\
\hline João Álvares de Carvalho & Maranhão & & \\
\hline Domingos Duarte Sardinha & & \\
\hline
\end{tabular}

Tabela 5. Percursos dos capitães-mores do Maranhão na governação ultramarina Fonte: ANTT. Mesa da Consciência e Ordens. HOC. Letra F, maço 35, n. ${ }^{\circ}$ 77. Chanc. D. Pedro II. L. 21, fls. 294-294v; L. 28, fls. 367-368; L. 61, fl. 264. Chanc. D. João V. L. 51, fls. 5v-6v; L. 67, fls. 166-167v; L. 82, fls. 9-10; L. 95, fls. 252v-254v; L. 110, fls. 174-174v. RGM. D. João V. L. 12, fls. $291-$ 291v; L. 19, fl. 227; L. 38, fl. 372. (LIMA, 2006, p. 351). (BERREDO, 1849, I. II, p. 560-563 e p. 600).

De acordo com a Tabela 5, Francisco Manuel da Nóbrega e Vasconcelos seguiu para o governo das ilhas de Cabo Verde. Uma ascensão em relação ao anterior se observada a diferença da patente, de capitão-mor para governador e capitão-general, e o fato de ter saído de uma capitania que se pode considerar em "situação transitória de subalternidade" e não subalterna, pois o Maranhão era a cabeça do Estado, para um governo principal. Um caso que ilustra essa conexão é o do sargento-mor Gonçalo de Lemos Mascarenhas, para quem o Maranhão foi uma via de acesso ao governo da também subalterna capitania de Sergipe d'El Rei (dessa vez com a patente de capitãomor), de onde passou em 1702 a governador e capitão-general de Cabo Verde. ${ }^{45}$

Assim como seu antecessor, D. Francisco Ximenes de Aragão também descreveu uma trajetória que não era propriamente original entre os governantes do Maranhão, ainda que em sentido inverso ao do circuito percorrido por Fernão Carrilho no final 
do século XVII. Este sertanista governou interinamente o Ceará de 1693 a 1694 e só depois da terceira candidatura ao posto de capitão-mor, em 1699, foi finalmente escolhido (STUDART, 2001, t. 1, p. 95-98 e p. 115-116). Não tomou posse no cargo porque no mesmo ano passou ao serviço do governador e capitão-general Antônio de Albuquerque Coelho de Carvalho, o moço, como seu loco-tenente ${ }^{46}$, servindo no Pará, no Maranhão e governando interinamente o Estado cerca de um ano (1701-1702).

Na investigação sobre o circuito percorrido por Damião de Bastos foram constatados alguns precedentes envolvendo os governos do Estado do Maranhão e da capitania subalterna do Pará. Casos como o de Sebastião de Lucena de Azevedo, capitão-mor do Pará (1646-1648), que seguiu com a mesma patente para o presídio de Benguela (DELGADO, 1945, p. 401) e o de Luís de Magalhães, promovido a governador e capitãogeneral do Estado do Maranhão (1649-1652) depois de seis anos como capitão-mor de Cacheu. ${ }^{47}$

Para estabelecer em linhas gerais o sentido dos deslocamentos verificados nas trajetórias governativas de Francisco Manuel da Nóbrega e Vasconcelos, D. Francisco Ximenes de Aragão e Damião de Bastos, bem como entender o que as sucessivas nomeações representaram em suas carreiras, é preciso apontar sumariamente alguns aspectos político-administrativos e considerar a posição das praças por eles governadas na hierarquia dos postos governativos no Império português. Sobre isto, acredita-se que houvesse em meados do século XVIII uma equivalência ou igual "predicamento" - para usar um termo da época - entre os governos do Maranhão e de Cacheu, como se depreende do requerimento de Pedro da Silva Correia ao Conselho Ultramarino pedindo a prorrogação do prazo para apresentar seus papeis de serviços e se candidatar ao cargo de capitão-mor das duas praças, cujos editais haviam sido lançados. ${ }^{48} \mathrm{O}$ capitão-mor de Cacheu era subalterno ao governador e capitão-general de Cabo Verde, como previa o capítulo 12 do Regimento dado em 1664 a João Carvalho Moutinho: "hei por bem que enquanto servirdes o dito posto, estejais subordinado ao governador das ilhas de Cabo Verde de cujo distrito são aquelas povoações de Guiné" (CARREIRA, 1983, p. 107-108).

O arquipélago, por sua vez, situava-se em ponto estratégico para o comércio atlântico e o tráfico negreiro (MARTINS, 2015, p. 51). As relações comerciais entre o Estado do Maranhão, Cabo Verde e Cacheu para o fornecimento de africanos escravizados datavam do final do século XVII, quando a Companhia de Comércio do Maranhão, criada em 1682, ficou encarregada de abastecer a região de escravos da Guiné. Depois de 1690, com o agravamento da crise de mão de obra indígena no Estado do Maranhão, foram estabelecidos contratos com a Companhia de Cabo Verde e Cacheu para o transporte e comércio de africanos escravizados (CHAMBOULEYRON, 2006, p. 85-94).

A praça de Cacheu firmou-se, portanto, como um dos principais portos de onde provinham os africanos que abasteciam o Estado do Maranhão, de onde os comerciantes obtinham as chamadas drogas do sertão, enviadas para o Reino ou utilizadas no tráfico negreiro (BARBOSA, 2009, p. 16 e p. 73-111). No entanto, na primeira metade do século XVIII, aquela praça e a de Bissau - as principais feitorias dos Rios 
da Guiné - encontravam-se em situação precária: “Havia apenas um forte, junto à foz do rio Cacheu", com os capitães-mores constantemente solicitando meios para reparar as fortificações e prover o armamento necessário à defesa dos interesses lusos na Guiné (MARTINS, 2015, p. 54).

Quanto à hierarquização dos governos no Atlântico português no século XVIII, similarmente à ocorrência de uma "subalternização do território" de Cabo Verde observada por Mafalda Soares da Cunha para o século XVII (CUNHA, 2005, p. 80-82), Nuno Gonçalo Monteiro constatou o que chamou de "periferização" daquela e de outras praças da África ocidental, pela decadência econômica verificada desde a centúria anterior (MONTEIRO, 2005, p. 104-105), o que teria repercutido negativamente na qualidade dos indivíduos recrutados para governos como o de Cabo Verde, São Tomé e Cacheu. Nesse sentido, em relação à origem social, Francisco Manuel da Nóbrega e Vasconcelos estaria situado entre os 11 "nobres" que governaram Cabo Verde de 1702 a 1818, enquanto Gonçalo de Lemos Mascarenhas poderia ser enquadrado na mesma categoria ou no grupo de cinco "fidalgos" identificados pelo historiador como governadores do arquipélago no mesmo período (MONTEIRO, 2005, p. 115), pois era filho de um fidalgo da Casa Real e alegava ser descendente de D. Nuno Mascarenhas, senhor de Palma. ${ }^{49}$

Em relação ao perfil profissional, Zelinda Cohen apontou que a maioria dos indivíduos providos no governo de Cabo Verde era de militares com tempo de serviço bastante para tal nomeação, mas não o suficiente para alcançarem postos mais elevados, como os governos do Rio de Janeiro, de Angola, de Pernambuco, Paraíba e Maranhão, como afirmaram dois membros do Conselho Ultramarino, em 1722. Por isso, aceitavam o governo de Cabo Verde e as condições que Ihes eram oferecidas, pois se fossem mais qualificados dariam preferência a comissões mais rentáveis na América portuguesa ou no Oriente (COHEN, 2002, v. III, p. 94-95). Por outro lado, os conselheiros devem ter se referido ao cargo de governador e capitão-general do Estado do Maranhão e não ao de capitão-mor da capitania, ocupado por Francisco Manuel da Nóbrega e Vasconcelos. Nesse caso, o governo de Cabo Verde pode ser tido como superior ao do Maranhão e, portanto, uma promoção para Vasconcelos, de resto agraciado com o hábito de Cristo por seus mais de 30 anos de serviços militares, antes de seguir para as ilhas.

Sobre os governantes de Cacheu, de acordo com dados recolhidos por Mafalda Soares da Cunha para o século XVII, em termos de origem "a extração social destes governantes era relativamente baixa, sobretudo composta por gente que tinha, quando muito nobreza pessoal de origem" (CUNHA, 2005, p. 82). Na centúria seguinte, a qualidade dos capitães-mores não sofreu alterações sensíveis, como mostra a classificação dos governantes de Cacheu de 1707 a 1803 (MONTEIRO, 2005, p. 115), período que compreende a nomeação de Damião de Bastos.

Ocupada pelos portugueses por volta do último quartel do século XVI, a capitania/ presídio de Benguela tornou-se um governo-geral separado da jurisdição de Angola pela provisão de 14 de fevereiro de 1615 (DELGADO, 1945, p. 38-41), tendo sido nomeado Manuel Cerveira Pereira para governador, a quem foi dado um Regimento com data 
de 26 de março daquele ano (COUTO, 1981, p. 285). Essa situação perdurou algumas décadas até que as necessidades de socorro a Luanda, ocupada pelos holandeses, levaram à revogação da decisão tomada em 1615. Benguela ficou subordinada a Angola até 1779, quando passou a ter um governador independente, com um novo Regimento para se orientar na administração (DELGADO, 1953, v. 3, p. 41-46).

Em Benguela "era o capitão-mor do presídio quem os comerciantes escolhiam para despachar os seus navios com mantimentos; processo este que punha, na mão da citada autoridade, o monopólio do comércio dos víveres, que a enchia de cabedais e a tornava dependente dos particulares" (DELGADO, 1945, p. 383-384). Na primeira metade do século XVIII, grosso modo, os provimentos de capitães-mores escolhidos mediante consulta ao Conselho Ultramarino atendiam a "pessoas pouco qualificadas", com pelo menos uma exceção apontada pelo autor, justamente um irmão de Francisco da Nóbrega e Vasconcelos, José da Nóbrega de Vasconcelos, que ao ser nomeado capitão-mor do presídio de Muxima teve ressaltado, além da participação na Guerra da Sucessão Espanhola, o fato de "ser pessoa nobre, neto de um desembargador que foi secretário da embaixada a que foi o marquês de Cascais (...) a El Rei de França" (COUTO, 1972, p. 59).

A diferença de patentes pode até ser um indicador de ascensão mais claro e menos suscetível à influência de outros elementos, mas não a dos soldos. Os vencimentos do capitão-mor de Benguela são um exemplo de como o soldo não deve ser tomado isoladamente para se aferir o valor de um cargo e compreender se os deslocamentos em determinado circuito governativo significaram ou não uma promoção. Damião de Bastos saiu do Maranhão, onde o capitão-mor vencia 400 mil reis de soldo, para receber em 1737 pelo governo de Cacheu, com a mesma patente e em outra capitania subordinada, exatamente a metade. Aí reside um aspecto que ilustra o cuidado necessário ao tomar os soldos como indicadores de promoção. No Estado do Maranhão, até 1749, não circulava moeda metálica e os pagamentos eram feitos com a chamada "moeda da terra" (grãos de cacau e rolos de pano de algodão), cujo poder de compra era inferior ao do dinheiro em metal (LIMA, 2006). Por isso, comparar valores nominais de soldos, sem atentar para especificidades locais, pode não assegurar um resultado confiável. Em outra situação, quando foi nomeado capitão-mor de Benguela, em 1748, a julgar que os rendimentos do cargo ainda montavam a 300 mil reis (AGUIAR, 2006, v. II, p. 124), Damião de Bastos continuou auferindo valores mais baixos em termos nominais, aparentemente compensados simbolicamente com a mercê de uma patente de mestre de campo ad honorem ${ }^{50}$, isto é, sem vencimentos, e possivelmente complementados com outras vantagens ao alcance dos capitães-mores daquele presídio de Angola (CANDIDO, 2013, p. 244).

Por fim, a última conexão a ser examinada diz respeito ao percurso de D. Francisco Ximenes de Aragão, do Maranhão para o Ceará. Quanto à patente, esse deslocamento não constituiu uma promoção na sua carreira de administrador colonial, pois em ambos os cargos governou com o título de capitão-mor e em situação de subalternidade - a capitania do Maranhão encontrava-se subordinada ao governo-geral do Estado, instalado no Pará, enquanto a do Ceará, outrora subordinada àquela repartição, 
passara à jurisdição de Pernambuco. Em outras palavras, D. Francisco Ximenes de Aragão descreveu uma trajetória daquelas que Leonardo Paiva de Oliveira denominou "regionalizadas", caracterizadas pela circulação de indivíduos pelo governo de capitanias próximas, de graduação equivalente e que não se encontravam entre os principais postos governativos da América portuguesa (OLIVEIRA, 2018, p. 104-105).

\section{Considerações finais e outras perspectivas de abordagem}

A criação do Estado do Grão-Pará e Maranhão, em 1751, sinalizou transformações na estrutura política e na dinâmica de governo do antigo Estado do Maranhão e Grão-Pará. A principal mudança certamente foi a inversão hierárquica entre as suas principais capitanias, tornando-se a do Pará cabeça do novo governo geral e a do Maranhão sua subalterna. Em São Luís passou a existir um governador subordinado ao governador e capitão-general em Belém, que por sua vez não se deslocava desta cidade para a antiga capital do Estado, invertendo o circuito percorrido pelos seus antecessores até a metade do século XVIII. No bojo dessas alterações, a figura do capitão-mor de governo deixou de existir tanto no Maranhão quanto no Pará.

Os quatro primeiros capitães-mores providos pelos governadores e capitãesgenerais para substituí-los em São Luís, desde que foram instruídos a fixar residência em Belém a partir de 1673, eram claramente interinos e governaram por subdelegação de poderes anteriormente delegados ao seu superior pelo rei. Ao longo do período de 1673 a 1751, o caráter provisório do governo dos capitães-mores no Maranhão nunca desapareceu completamente, porque embora permanecessem cada vez mais em Belém, os governadores e capitães-generais retornavam, ainda que por breve tempo, a São Luís. Justamente por esse motivo, desfizeram-se impressões iniciais de que a nomeação de capitães-mores efetivos para a capitania do Maranhão era incoerente com a forma pela qual o Conselho Ultramarino procedia à seleção dos governantes do Estado do Maranhão e com a sua própria estrutura político-administrativa. Afinal, o órgão era responsável por receber e escrutinar as candidaturas aos postos de capitão-mor e de governador e capitão-general para dois espaços jurisdicionais distintos, respectivamente, a capitania e o Estado do Maranhão.

Como aceitar que não havia uma incongruência nesse processo? A resposta está na durabilidade da dinâmica administrativa em que o Pará assumia a condição de cabeça do Estado com a transferência do governador e capitão-general para lá, munido de todos os seus poderes e jurisdições, enquanto o Maranhão ficava em situação de subalternidade. Um sinal de que esse processo se sedimentava já no final do século XVII aparece na carta patente de João Duarte Franco, o primeiro nomeado pelo rei, pelo tempo de três anos e enquanto não houvesse um sucessor, como regra geral se praticava nos provimentos de governantes ultramarinos. ${ }^{51}$

A transferência dos governadores e capitães-generais para a capitania do Pará e a sua consequente ausência de São Luís propiciou a gradativa transformação de Belém em capital política do Estado do Maranhão e Grão-Pará, posição que alcançou definitivamente na metade do século XVIII como cabeça do Estado do Grão-Pará e 
Maranhão. A dupla capitalidade existente no Norte amazônico no período colonial, as relações entre as duas principais cidades da região e, em especial, a construção histórica da capitalidade de Belém são processos que merecem uma abordagem mais cuidadosa da historiografia. Por ora, vale tomar de empréstimo a afirmação de Catarina Madeira Santos: "tal como no Reino, no Oriente, capitalidade e itinerância, longe de se excluírem, constituíam realidades conciliáveis e coexistentes" (SANTOS, 1999, p. 157).

Como foi dito na introdução, o estudo das trajetórias dos 13 capitães-mores não tinha, nem poderia ter, a pretensão de esgotar todas as possibilidades de compreender as suas "histórias de vida". Outros aspectos, portanto, ainda podem ser aprofundados em um eventual prosseguimento das investigações. No que diz respeito à administração do Maranhão é possível discutir a existência ou não de prerrogativas jurisdicionais para os capitães-mores exercerem o governo político da capitania ou somente o governo das armas. Quanto aos circuitos governativos, os sentidos dos percursos podem vir a ser explorados por meio de estudos de casos - há, por exemplo, quantidade expressiva de registros dos governos de Francisco Manuel da Nóbrega e Vasconcelos e de Damião de Bastos, respectivamente, em Cabo Verde e Cacheu, no Arquivo Histórico Ultramarino. Um exame mais acurado dessas experiências pode reforçar as conexões entre o Maranhão e aqueles territórios da costa ocidental da África e contribuir para um melhor entendimento dos deslocamentos dos agentes.

\section{Referências}

ABREU, J. C. de. Capítulos de história colonial. 6 ed. Rio de Janeiro: Civilização Brasileira; Brasília: INL, 1976.

AGUIAR, P. L. de. Administração colonial portuguesa no Congo, em Angola e em Benguela, v. II (1694-1799). Lisboa: Sociedade Histórica da Independência de Portugal, 2006.

BAENA, A. L. M. Compêndio das eras da província do Pará. Belém: Tipografia de Santos \& Santos Menor, 1838.

BAENA, A. L. M. Ensaio corográfico sobre a província do Pará. Brasília: Edições do Senado Federal, 2004.

BARBOSA, Benedito Carlos Costa. Em outras margens do Atlântico: tráfico negreiro Social da para o Estado do Maranhão e Grão-Pará (1707-1750). Dissertação (Mestrado em História) - Instituto de Filosofia e Ciências Humanas, Universidade Federal do Pará, Belém, 2009.

BARDWELL, R. L. The governors of Portugal's South Atlantic Empire in the seventeenth century: social background, qualifications, selection and reward. Tese (Doutorado em História) - University of California, Santa Barbara, 1974. 
BERREDO, B. P. de. Annaes historicos do Estado do Maranhão, em que se dá notícia do seu descobrimento, e tudo o mais que nelle tem succedido desde o anno em que foy descuberto até o de 1718. 2 ed. São Luiz: Typographia Maranhense, 1849, livros I e II.

BETTENDORFF, J. F. Crônica da missão dos padres da Companhia de Jesus no Estado do Maranhão. 2 ed. Belém: Fundação Cultural do Pará Tancredo Neves; Secretaria de Estado da Cultura, 1990.

BOURDIEU, P. A ilusão biográfica. In: FERREIRA, M. de M.; AMADO, J. (orgs.). Usos \& abusos da história oral. 8 ed. Rio de Janeiro: FGV, 2006, p. 183-191.

CANDIDO, M. P. O limite tênue entre liberdade e escravidão em Benguela durante a era do comércio transatlântico. Afro-Ásia, Salvador, n. 47, p. 239-268, 2013.

CARDOSO, Alírio Carvalho. Maranhão na monarquia hispânica: intercâmbios, guerra e navegação nas fronteiras das Índias de Castela (1580-1655) - Facultad de Geografía e Historia, Departamento de Historia Medieval, Moderna, Contemporánea y de América, Universidad de Salamanca, Salamanca, 2012.

CARREIRA, A. Documentos para a história das llhas de Cabo Verde e "Rios de Guiné" (séculos XVII e XVIII). Lisboa: Ed. do Autor, 1983.

CHAMBOULEYRON, R. Escravos do Atlântico equatorial: tráfico negreiro para o Estado do Maranhão e Pará (século XVII e início do século XVIII). Revista Brasileira de História, São Paulo, n. 52, v. 26, 2006, p. 79-114.

CHAMBOULEYRON, R. Povoamento, ocupação e agricultura na Amazônia colonial (1640-1706). Belém: Ed. Açaí; PPGH (UFPA); Centro de Memória da Amazônia (UFPA), 2010.

CHARLE, C. A prosopografia ou biografia coletiva: balanço e perspectivas. In: HEINZ, F. M. (org.). Por outra história das elites. Rio de Janeiro: FGV, 2006, p. 41-53.

COHEN, Z. A administração das ilhas de Cabo Verde pós-União Ibérica: continuidades e rupturas. In: SANTOS, M. E. M. (coord.). História Geral de Cabo Verde. Lisboa/ Praia: Instituto de Investigação Científica Tropical; Instituto Nacional de Investigação, Promoção e Patrimônio Culturais de Cabo Verde, 2002, v. III, p. 67-156.

CORRÊA, H. M. M. "Para aumento da conquista e bom governo dos moradores": a Câmara de São Luís e a política da monarquia pluricontinental no Maranhão. In: FRAGOSO, J.; SAMPAIO, A. C. J. de (orgs.). Monarquia pluricontinental e a governança da terra no ultramar atlântico luso, séculos XVI-XVIII. Rio de Janeiro: Mauad X, 2012, p. 23-49.

COSENTINO, F. C. Governadores Gerais do Estado do Brasil (séculos XVI-XVII): ofício, regimentos, governação e trajetórias. São Paulo: Annablume/Fapemig, 2009.

COUTO, C. Os capitães-mores em Angola no século XVIII (subsídio para o estudo da sua actuação). Luanda: Instituto de Investigação Científica de Angola, 1972.

COUTO, C. Regimento de governo subalterno de Benguela. STVDIA, Lisboa, n. 45, p. 285-294, jan./jun. de 1981. 
CUNHA, M. S. da; MONTEIRO, N. G. Governadores e capitães-mores do império atlântico português nos séculos XVII e XVIII. In: MONTEIRO, N. G. F.; CARDIM, P.; CUNHA, M. S. da (orgs.). Optima Pars. Elites ibero-americanas do Antigo Regime. Lisboa: ICS/ Imprensa de Ciências Sociais, 2005, p. 191-252.

CUNHA, M. S. da. Governo e governantes do Império português do Atlântico (século XVII). In: BICALHO, M. F.; FERLINI, V. L. A. (orgs.). Modos de governar: ideias e práticas políticas no Império português (séculos XVI a XIX). São Paulo: Alameda, 2005, p. 69-92.

DELGADO, R. História de Angola (Terceiro período, de 1648 a 1836). Lobito: Oficinas Gráficas da Livraria Magalhães, 1953, v. 3.

DELGADO, R. O Reino de Benguela (Do descobrimento à criação do governo subalterno). Lisboa: Imprensa Beleza, 1945.

FONSECA, Marcos Arthur Viana da. Sob a sombra dos governadores de Pernambuco? Jurisdição e administração dos capitães-mores da capitania do Rio Grande (17011750). Dissertação (Mestrado em História) - Centro de Ciências Humanas, Letras e Artes, Universidade Federal do Rio Grande do Norte, Natal, 2018.

GODINHO, V. M. Estrutura da antiga sociedade portuguesa. 2 ed. Lisboa: Arcádia, 1975.

LEVI, G. Usos da biografia. In: FERREIRA, M. de M.; AMADO, J. (orgs.). Usos \& abusos da história oral. 8 ed. Rio de Janeiro: FGV, 2006, p. 167-182.

LÉVILLAIN, P. Os protagonistas: da biografia. In: RÉMOND, R. (org.). Por uma história política. 2 ed. Rio de Janeiro: FGV, 2003, p. 141-184.

LIMA, Alam José da Silva. Do "dinheiro da terra" ao "bom dinheiro". Moeda natural e moeda metálica na Amazônia colonial (1706-1750). Dissertação (Mestrado em História) - Instituto de Filosofia e Ciências Humanas, Universidade Federal do Pará, Belém, 2006.

LIMA, C. de. História do Maranhão - v. 1: A Colônia. 2 ed. São Luís: Instituto Geia, 2006.

LORIGA, S. O pequeno x: da biografia à história. Belo Horizonte: Autêntica Editora, 2011.

MARQUES, C. A. Diccionario histórico-geographico da provincia do Maranhão. São Luiz: Typographia do Frias, 1870.

MARQUES, C. A. Jozé da Cunha d’Eça (História do Maranhão). R. IHGB, Rio de Janeiro, t. 59, parte II, p. 47-55, 1896.

MARTINS, Diego de Cambraia. O tráfico de escravos nos Rios da Guiné e a dinâmica da economia atlântica portuguesa (1756-1807). Dissertação (Mestrado em História) Faculdade de Filosofia, Letras e Ciências Humanas, Universidade de São Paulo, São Paulo, 2015.

MATOS, G. de M. de. Um soldado de fortuna do século XVII. Lisboa: Tip. Inácio Pereira Rosa Ltda., 1939.

MELLO, M. E. A. de S. e. Fé e império: as juntas das missões nas conquistas portuguesas. Manaus: EDUFAM, 2009. 
MENDONÇA, M. C. de (coord.) A Amazônia na era pombalina. Correspondência inédita do governador e capitão-general do Estado do Grão-Pará e Maranhão Francisco Xavier de Mendonça Furtado (1751-1759). Rio de Janeiro: IHGB, 1963, t. I.

MONTEIRO, N. G. Governadores e capitães-mores do Império Atlântico Português no século XVIII. In: BICALHO, M. F.; FERLINI, V. L. A. (orgs.). Modos de governar: ideias e práticas políticas no Império português (séculos XVI a XIX). São Paulo: Alameda, 2005, p. 93-115.

OLIVEIRA, Leonardo Paiva de. Capitães-mores das Capitanias do Norte: perfis, trajetórias e hierarquias espaciais no Rio Grande e Ceará (1656-1755). Dissertação (Mestrado em História) - Centro de Ciências Humanas, Letras e Artes, Universidade Federal do Rio Grande do Norte, Natal, 2018.

PELEGRINO, Alexandre de Carvalho. Donatários e poderes locais no Maranhão seiscentista (1621-1701). Dissertação (Mestrado em História) - Instituto de Ciências Humanas e Filosofia, Universidade Federal Fluminense, Niterói, 2015.

PRADO JÚNIOR, C. Formação do Brasil contemporâneo. 14 ed. São Paulo: Brasiliense, 1976.

RAMINELLI, R. Nobrezas do Novo Mundo: Brasil e ultramar hispânico, séculos XVII e XVIII. Rio de Janeiro: FGV/Faperj, 2015.

ROCHA, Rafael Ale. A elite militar no Estado do Maranhão: poder, hierarquia e comunidades indígenas (século XVII). Tese (Doutorado em História) - Instituto de Ciências Humanas e Filosofia, Universidade Federal Fluminense, Niterói, 2013.

ROLIM, Leonardo Cândido. A Rosa dos Ventos dos Sertões do Norte: dinâmicas do território e exploração colonial (c.1660-c.1810). Tese (Doutorado em História) - Faculdade de Filosofia, Letras e Ciências Humanas, Universidade de São Paulo, São Paulo, 2018.

SALDANHA, A. V. de. As capitanias do Brasil: antecedentes, desenvolvimento e extinção de um fenómeno atlântico. 2 ed. Lisboa: Comissão Nacional para as Comemorações dos Descobrimentos Portugueses, 2001.

SANTOS, C. M. "Goa é a chave de toda a Índia": perfil político da capital do Estado da Índia (1505-1570). Lisboa: Comissão Nacional para as Comemorações dos Descobrimentos Portugueses, 1999.

SANTOS, F. V. Os capitães-mores do Pará (1707-1737): trajetórias, governo e dinâmica administrativa no Estado do Maranhão. Topoi, Rio de Janeiro, v. 16, n. 31, p. 667-688, jul./dez. 2015.

SANTOS, F. V. Entre São Luís e Belém: um estudo da dinâmica de governo no Estado do Maranhão e Grão-Pará (1673-1751). In: BORGES, E. J. S.; FLEXOR, M. H. O.; SEVERS, S. M. de S. S. (orgs.). Poderes, identidades e sociedade na América portuguesa (séculos XVI-XVIII). São Paulo: Alameda, 2017.

SILVA, A. de M. Diccionario da lingua portugueza composto pelo padre D. Rafael Bluteau, reformado e accrescentado por ..., natural do Rio de Janeiro. Lisboa: Na Officina de Simão Thaddeo Ferreira, 1789, tomo segundo. 
STONE, L. Prosopography. The Past \& Present, Boston/London, p. 45-73, 1981.

STUDART, G. Datas e factos para a história do Ceará. Fortaleza: Fundação Waldemar Alcântara, 2001, t. 1.

VARNHAGEN, F. A. de. História Geral do Brazil. Rio de Janeiro: E. e H. Laemmert, 1857, t. 2.

WEHLING, M. J. M. C. de M. O Estado do Maranhão na União Ibérica. R. IHGB, Rio de Janeiro, 166 (426), p. 57-86, jan./mar. 2005.

\section{Notas}

${ }^{1}$ A partir de 1751 chamou-se Estado do Grão-Pará e Maranhão, tendo por capital a cidade de Belém e a capitania do Pará por cabeça. O Maranhão passou a ser subordinado ao Pará e administrado por um governador. A jurisdição do Estado do Grão-Pará incluía as capitanias subalternas de São José do Rio Negro e de São José do Piauí. Em 1772/74 nova divisão administrativa deu origem ao Estado do Grão-Pará e Rio Negro e ao Estado do Maranhão e Piauí.

${ }^{2}$ ANTT. Chancelaria de D. Pedro II. Livro 48, fl. 13.

${ }^{3}$ Arquivo Histórico Ultramarino (AHU). Códice 268, fls. 19v-20 e 22v.

${ }_{4}^{4} \mathrm{AHU}$. Projeto Resgate. Pará (avulsos). Cx. 5, D. 621.

${ }^{5} \mathrm{AHU}$. Projeto Resgate. Pará (avulsos). Cx. 5, D. 621.

6 AHU. Códice 2107[1107], fls. 9v-10.

7 Sabe-se, por exemplo, que Pascoal Paes Parente substituiu alguns governadores ao deixarem São Luís rumo a Belém: “(...) e indo os governadores Antônio de Albuquerque, e Pedro César de Meneses à capitania do Pará o deixarem [sic] em seu lugar governando o Maranhão (...)", não se sabe se com a patente de capitão-mor. Isso, no entanto, ocorreu antes de 1673. Revista do Instituto do Ceará. Fortaleza, t. XXXV, p. 82-84, 1921.

8 Biblioteca da Ajuda (BA). 54-XI-27, n. ${ }^{17}$. Memória das pessoas que desde o princípio da conquista governaram as duas capitanias, do Maranhão e Grão-Pará (1783), fl. 10v.

9BA. 54-XI-27, n० 17, fl. 9v.

10 BA. 51-V-43, fls. 13-13v.

11 AHU. Códice 18, fl. 88v. Projeto Resgate. Maranhão (avulsos). Cx. 7, D. 759.

12 AHU. Códice 18, fls. 92v-93.

${ }^{13}$ Arquivo Nacional da Torre do Tombo (ANTT). Registro Geral de Mercês. D. Pedro II. Livro 4, fl. $468 \mathrm{v}$.

${ }^{14}$ Arquivo Público do Estado do Maranhão (APEM). Acervo Digital. Câmara Municipal de São Luís. Copiador de Cartas (1689-1720). Livro 24, fls. 11v-13v.

${ }_{15}$ ANTT. Registro Geral de Mercês. D. Pedro II. Livro 5, fl. 84v; Chancelaria de D. Pedro II. Livro 21, fls. 294-294v. Carta patente de 14 de março de 1693 pela qual João Duarte Franco foi nomeado capitão-mor da capitania de São Luís do Maranhão. Essa informação contraria o "Catálogo" da 
Biblioteca Pública de Évora, segundo o qual o governo de João Duarte Franco começou em 1698.

${ }^{16}$ APEM. Acervo Digital. Câmara Municipal de São Luís. Copiador de Cartas (1689-1720). Livro 24, fls. 33v-34.

17 APEM. Acervo Digital. Câmara Municipal de São Luís. Copiador de Cartas (1689-1720). Livro 24, fls. 39-40.

18 AHU. Códice 268, fl. 270v.

19 AHU. Projeto Resgate. Maranhão (avulsos). Cx. 10, D. 1085 e Cx. 11, D. 1128.

${ }^{20}$ ANTT. Registro Geral de Mercês. D. João V. Livro 30, fl. 291v. Provisão de 27 de abril de 1723.

${ }^{21}$ ANTT. Mesa da Consciência e Ordens. HOC. Letra F, maço 36, n 56 . O processo de habilitação de Pascoal Paes Parente está apenso ao do irmão, Francisco Paes Parente.

22 ANTT. Registro Geral de Mercês. D. Pedro II. Livro 14, fl. 392v.

${ }^{23}$ ANTT. Mesa da Consciência e Ordens. HOC. Letra F, maço 35, $\mathrm{n}^{\circ} 77$.

${ }^{24}$ ANTT. Mesa da Consciência e Ordens. HOC. Letra P, maço 10, nº 8.

${ }^{25}$ ANTT. Mesa da Consciência e Ordens. HOC. Letra F, maço 36, n 56.

${ }^{26}$ Para uma definição de morgado e capela, dois tipos de vínculos existentes em Portugal, instituídos para assegurar a posse indissolúvel e inalienável de um conjunto de bens por uma família, ver (GODINHO, 1975, p. 93-94).

${ }^{27}$ ANTT. Mesa da Consciência e Ordens. HOC. Letra F, maço 35, n 77. Sobre Manuel da Nóbrega, cf. ANTT. Registro Geral de Mercês. Mercês da Torre do Tombo. Livro 17, fls. 24v-25. Sobre o morgado e a capela instituídos pelo Dr. Francisco da Nóbrega, cf. ANTT. Chancelaria de D. João V. Livro 117, fls. 45-45v; Livro 124, fls. 153-153v e Livro 126, fls. 331-331v. Em seu testamento, de 3 de abril de 1759, Francisco Manuel da Nóbrega e Vasconcelos declarou: “(...) eu não tenho dinheiro algum nem peças de ouro ou prata porque todas vendi por me ser necessário valer delas por me não chegarem os rendimentos dos bens vinculados pela danificação em que se acham antes sou devedor de muitos encargos dos mesmos vínculos". ANTT. Feitos Findos. Registro Geral de Testamentos. Livro 279, fls. 88-89.

${ }^{28}$ ANTT. Registro Geral de Mercês. D. Pedro II. Livro 14, fl. 392v. Alvarás de 20 e 21 de abril de 1702. Sobre a graduação dos foros de fidalgo da Casa Real recebidos por José da Cunha d' Eça e Francisco Manuel da Nóbrega e Vasconcelos, cito: "Existiam duas ordens de fidalgos, sendo a primeira superior a segunda. Na primeira, estavam o fidalgo cavaleiro, fidalgo escudeiro e moço fidalgo; na segunda, o cavaleiro fidalgo, escudeiro fidalgo e moço de câmara. Assim, o fidalgo cavaleiro era o título mais honroso, enquanto o moço de câmara o menos prestigioso" (RAMINELLI, 2015, p. 33).

${ }^{29}$ ANTT. Chancelaria de D. Pedro II. Livro 28, fls. 367-368.

30 ANTT. Chancelaria de D. Pedro II. Livro 48, fl. 13.

${ }^{31}$ ANTT. Chancelaria de D. João V. Livro 110, fls. 174-174v.

32 ANTT. Registro Geral de Mercês. D. João V. Livro 12, fls. 291-291v 
${ }^{33}$ APEM. Acervo Digital. Câmara Municipal de São Luís. Correspondências recebidas (1694-1737). Livro 66, fls. 17/17 e 17/18.

${ }^{34}$ APEM. Acervo Digital. Câmara Municipal de São Luís. Correspondências recebidas (1694-1737). Livro 66, fl. 18.

${ }^{35}$ BA. 51-V-43, fls. 30-35.

36 AHU. Projeto Resgate. Maranhão (avulsos). Cx. 11, D. 1092.

${ }^{37}$ Arquivo da Universidade de Coimbra (AUC). Coleção Condes dos Arcos (Pará). VI-III-1-1-30.

${ }^{38}$ BA. 51-V-44, fl. 67.

39 AHU. Projeto Resgate. Maranhão (avulsos). Cx. 11, D. 1125 e 1139.

${ }^{40} \mathrm{AHU}$. Códice 270, fls. 248-249 (carta régia de 26/03/1737); 252v-253 (carta régia de 23 e 24 de março de 1737); 255 (carta régia de 28/03/1737) e 261v (carta régia de 29/05/1737). Códice 271, fls. 47-47v (carta régia de 02/07/1744).

${ }^{41} \mathrm{AHU}$. Projeto Resgate. Maranhão (avulsos). Cx. 17, D. 1761.

42 AHU. Projeto Resgate. Maranhão (avulsos). Cx. 17, D. 1763.

${ }^{43} \mathrm{AHU}$. Projeto Resgate. Maranhão (avulsos). Cx. 17, D. 1768. Ofício de 6 de outubro de 1729.

${ }^{44} \mathrm{AHU}$. Projeto Resgate. Maranhão (avulsos). Cx. 17, D. 1797. Ofício de 10 de março de 1730.

45 ANTT. Chancelaria de D. Pedro II. Livro 21, fls. 157v-158v. Carta patente de capitão-mor da capitania de Sergipe d'El Rei, de 4 de setembro de 1692; Livro 27, fls. 150v-151. Carta patente de governador e capitão-general de Cabo Verde, de 12 de abril de 1702.

${ }^{46}$ ANTT. Registro Geral de Mercês. D. Pedro II. Livro 12, fl. 373. Carta patente de 18 de setembro de 1699.

${ }^{47}$ ANTT. Registro Geral de Mercês. Mercês da Torre do Tombo. Livro 17, fls. 19-20.

48 AHU. Projeto Resgate. Maranhão (avulsos). Cx. 31, D. 3207.

49 AHU. Projeto Resgate. Sergipe (avulsos). Cx. 1, D. 57. ANTT. Registro Geral de Mercês. D. Pedro II. Livro 4, fl. $468 \mathrm{v}$.

${ }^{50}$ ANTT. Registro Geral de Mercês. D. João V. Livro 38, fl. 372. Carta patente de 12 de agosto de 1748.

51 ANTT. Chancelaria de D. Pedro II. Livro 21, fls. 294-294v.

Fabiano Vilaça dos Santos é professor Doutor - ORCID: https://orcid.org/0000-0002-53625923, Departamento de História e do Programa de Pós-graduação em História - Instituto de Filosofia e Ciências Humanas - UERJ - Universidade do Estado do Rio de Janeiro, Campus Maracanã - R. São Francisco Xavier, 524, $9^{\circ}$ andar, Sala 9024B, CEP 20550-900, Rio de Janeiro, RJ, Brasil. Investigador Colaborador do Centro de História - Universidade de Lisboa. E-mail: fabianovilaca@gmail.com 